\title{
Model complexes with naturally occurring ligands (salicylglycine and imidazol) and the biometals copper and cobalt
}

\author{
Evelina G. Ferrer ${ }^{\mathrm{a}, *}$, Ana C. González Baró ${ }^{\mathrm{a}}$, Eduardo E. Castellano ${ }^{\mathrm{b}}$, \\ Oscar E. Piro ${ }^{\mathrm{c}}$, Patricia A.M. Williams ${ }^{\text {a }}$ \\ a Centro de Química Inorgánica (CEQUINOR/CONICET, UNLP), Facultad de Ciencias Exactas, UNLP, C. Correo 962, 1900 La Plata, Argentina \\ b Instituto de Física de São Carlos, Universidade de São Paulo, C.P. 369, 13560 São Carlos (SP), Brazil \\ ${ }^{\mathrm{c}}$ Departamento de Física, Facultad de Ciencias Exactas, Universidad Nacional de La Plata e Instituto IFLP(CONICET) C.C. 67, \\ 1900 La Plata, Argentina
}

Received 2 July 2003; received in revised form 3 October 2003; accepted 7 November 2003

\begin{abstract}
Two new complexes $\left[\mathrm{Cu}(\mathrm{Imz})_{4} \mathrm{Cl}_{2}\right]\left[\mathrm{Cu}(\mathrm{Imz})_{4} \mathrm{Cl}\right]_{2}(2-\mathrm{OH}-\mathrm{Hip})_{2}(\mathbf{1})$ and $\left[\mathrm{Co}(2-\mathrm{OH}-\mathrm{Hip})(\mathrm{Imz})_{3}\right] \cdot \mathrm{H}_{2} \mathrm{O}(\mathbf{2})$ (with Imz $=\mathrm{Imidazol}$ and 2-OH-Hip = 2-hydroxyhippuric acid) were prepared and characterized. The molecular structures and the solution and solid state behavior of the complexes were investigated. Complex 1 crystallizes in the monoclinic space group $P 2_{1} / c$ with $a=16.880(1)$, $b=8.046(1), c=24.683(1) \AA, \beta=107.88(1)^{\circ}$, and $Z=2$, while complex 2 crystallizes in the orthorhombic space group $P b c a$ with $a=11.712(2), b=15.741(4), c=22.254(4) \AA$, and $Z=8$. The $\left[\mathrm{Cu}(\mathrm{Imz})_{4} \mathrm{Cl}_{2}\right]\left[\mathrm{Cu}(\mathrm{Imz})_{4} \mathrm{Cl}\right]_{2}(2-\mathrm{OH}-\mathrm{Hip})_{2}$ solid consists in two distinct monomeric $\mathrm{Cu}$ (II) complexes: one of them is neutral octahedral $\left[\mathrm{Cu}(\mathrm{Imz})_{4} \mathrm{Cl}_{2}\right]$ and the other, charged square basis pyramida $\left[\mathrm{Cu}(\mathrm{Imz})_{4} \mathrm{Cl}\right]^{+}$. The 2-hydroxyhippuric acid, which here acts as a counter ion, is deprotonated at its carboxylic group. Cobalt(III) ion in $\left[\mathrm{Co}(2-\mathrm{OH}-\mathrm{Hip})(\mathrm{Imz})_{3}\right] \cdot \mathrm{H}_{2} \mathrm{O}$ is at the center of an octahedral environment, coordinated to three Imidazol ligands and to a triply deprotonated 2-hydroxyhippuric acid molecule acting as a tridentate ligand. Aqueous solution equilibrium of the quaternary system $\mathrm{Cu}^{2+} / 2-\mathrm{OH}-\mathrm{Hip} / \mathrm{Imz} / \mathrm{H}^{+}$was studied by potentiometric titrations.
\end{abstract}

(C) 2003 Elsevier Inc. All rights reserved.

Keywords: 2-Hydroxyhippuric acid; Biometals; Imidazol; X-ray structure; Solution studies

\section{Introduction}

The interest in copper(II) and cobalt(III) peptidic complexes with Imidazol ligands, that are ligating moieties found in proteins, evolves from their biological implications. Peptides are efficient metal ion binders in biological systems and their complexes can be used as models of their recognition [1]. In addition, some copper(II) complexes that contain these ligands where found to have a variety of pharmacological activities [2]. The chemical speciation of an element, either essential or toxic, allows the knowledge of its biodisponibility,

\footnotetext{
Supplementary data associated with this article can be found, in the online version, at doi:10.1016/j.jinorgbio.2003.11.002.

${ }^{*}$ Corresponding author. Tel.: +54-0221-4259485; fax: +54-02214259485.

E-mail address: evelina@dalton.quimica.unlp.edu.ar (E.G. Ferrer).
}

transport and absorption properties in biofluids or tissues. It is then interesting to study the solution equilibrium of copper in the presence of these ligands.

Salicylglycine, 2-hydroxyhippuric acid (2-OH$\mathrm{HipH}_{2}$ ), a phase II metabolite of aspirin, contains the amide- $\mathrm{N}$ surrounded by hard $\mathrm{O}$ donor functional groups. Several transition metal complexes with this ligand have been reported [3-8]. In most cases, the presence of anchoring groups, which can strongly bind metal ions, produces peptide-amide deprotonation in aqueous solution, at physiological $\mathrm{pH}[5,9]$.

In order to evaluate the coordination sites of this ligand, the preparation, structural and spectroscopic characterization of the complexes [Co(2-OH-Hip)$\left.(\operatorname{Imz})_{3}\right] \cdot \mathrm{H}_{2} \mathrm{O}$ and $\left[\mathrm{Cu}(\operatorname{Imz})_{4} \mathrm{Cl}_{2}\right]\left[\mathrm{Cu}(\mathrm{Imz})_{4} \mathrm{Cl}_{2}(2-\mathrm{OH}-\right.$ Hip) ${ }_{2}$, is described in the present paper. Due to the pharmacological interest of the copper-ligands systems, solution studies have been performed to determine the 
species distribution. The aim of this analysis was to obtain information about biodisponibility at different $\mathrm{pH}$ values and also to simulate naturally occurring mixtures of the metal ion and ligands.

\section{Preparative}

\section{1. $\left[\mathrm{Co}(2-\mathrm{OH}-\mathrm{Hip})(\mathrm{Imz})_{3}\right] \cdot \mathrm{H}_{2} \mathrm{O}$}

An aqueous solution of cobalt(II) nitrate hexahydrate $(0.5 \mathrm{mmoL}$ in $50 \mathrm{~mL})$ was dropwise added to an aqueous solution of 2-hydroxyhippuric acid $(1 \mathrm{mmoL}$ in 50 $\mathrm{mL}$ ) with constant stirring. The above solution was mixed with an ethanolic solution of Imidazol $(1 \mathrm{mmoL}$ in $50 \mathrm{~mL}$ ). The resulting $\mathrm{pH}$ of the mixture was 6 . The reaction system was left to stand and after 5 days dark red crystals suitable for X-ray study were formed. The diamagnetism of the sample denotes the oxidation of the metal center during the preparation (see below). Anal. Calcd. for $\mathrm{C}_{18} \mathrm{H}_{20} \mathrm{~N}_{7} \mathrm{O}_{5} \mathrm{Co}: \mathrm{C}, 45.7 ; \mathrm{H}, 4.2 ; \mathrm{N}, 20.7$. Found: C, 45.6; H, 4.3; N, 20.5\%.

\section{2. $\left[\mathrm{Cu}(\mathrm{Imz})_{4} \mathrm{Cl}_{2}\right]\left[\mathrm{Cu}(\mathrm{Imz})_{4} \mathrm{Cl}\right]_{2}(2-\mathrm{OH}-\mathrm{Hip})_{2}$}

The complex was synthesized similarly to the former Co(III) compound, using copper(II) acetate instead of cobalt(II) nitrate. The $\mathrm{pH}$ was kept at value of 6 , by the addition of $1 \mathrm{M} \mathrm{HCl}$. The magnetic moment was measured at room temperature, obtaining a value of 1.50 BM per copper atom (see below). Anal. Calcd. for $\mathrm{C}_{54} \mathrm{H}_{64} \mathrm{~N}_{26} \mathrm{O}_{8} \mathrm{Cu}_{3} \mathrm{Cl}_{4}: \mathrm{C}, 42.2 ; \mathrm{H}, 4.2 ; \mathrm{N}, 23.7$. Found: $\mathrm{C}$, $42.0 ; \mathrm{H}, 4.3 ; \mathrm{N}, 23.8 \%$.

\section{Experimental}

\subsection{Reagents and instrumentation}

All chemicals were of analytical grade. Copper(II) acetate monohydrate (Merck), Cobalt(II) nitrate hexahydrate (Merck), Imidazol (Riedel de Haën) and 2hydroxyhippuric acid (Sigma) were used as purchased.

IR spectra of powdered samples were measured with a Bruker IFS 66 FTIR-spectrophotometer from 4000 to $400 \mathrm{~cm}^{-1}$ in the form of pressed $\mathrm{KBr}$ pellets.

Electronic absorption spectra were recorded on a Hewlett-Packard 8453 diode-array spectrophotometer, using $1 \mathrm{~cm}$ quartz cells. The complexes have been dissolved in an aqueous $0.5 \mathrm{mM}$ solution $(0.150 \mathrm{M} \mathrm{NaCl}$ ionic strength, $\mathrm{pH}=5.5$ ). Diffuse reflectance spectra were registered with a Shimadzu UV-300 instrument, using $\mathrm{MgO}$ as an internal standard. Elemental analysis for carbon, hydrogen and nitrogen were performed using a Carlo Erba EA 1108 analyzer. Thermogravimetric (TG) and differential thermal analysis (DTA) were performed on a Shimadzu system (models TG-50 and DTA-50, respectively), working in an oxygen flow $(60 \mathrm{~mL} / \mathrm{min})$ at a heating rate of $10{ }^{\circ} \mathrm{C} / \mathrm{min}$. Sample quantities ranged between 10 and $20 \mathrm{mg}$. $\mathrm{Al}_{2} \mathrm{O}_{3}$ was used as a DTA standard. Room temperature magnetic susceptibilities were measured with a Cahn 2000 balance calibrated with $\mathrm{Hg}\left[\mathrm{Co}(\mathrm{SCN})_{4}\right]$ and using a field strength of $6 \mathrm{~kg}$.

\subsection{X-ray diffraction data}

Crystal data, data collection procedures, structure determination methods and refinement results for the two complexes are summarized in Table 1 [10-16].

In both complexes the $\mathrm{H}$-atoms were positioned stereo chemically and refined with the riding model. The location of the hydrogen atom on the oxhydryl group attached to the 2-hydroxyhippuric acid phenyl ring in $\left[\mathrm{Cu}(\operatorname{Imz})_{4} \mathrm{Cl}_{2}\right]\left[\mathrm{Cu}(\mathrm{Imz})_{4} \mathrm{Cl}\right]_{2}(2-\mathrm{OH}-\mathrm{Hip})_{2}$ was refined by rigid group rotation of the $\mathrm{O}-\mathrm{H}$ bond around the corresponding (ph)C-O direction such as to maximize the electron density at the calculated position. The water $\mathrm{H}$ atoms of $\left[\mathrm{Co}(2-\mathrm{OH}-\mathrm{Hip})(\mathrm{Imz})_{3}\right] \cdot \mathrm{H}_{2} \mathrm{O}$ were found in a difference Fourier map and refined with $\mathrm{Ow}-\mathrm{H}$ and $\mathrm{H} \cdots \mathrm{H}$ distances restrained to target values of $0.82(1)$ and 1.30(1) $\mathrm{A}$, respectively.

\subsection{Potentiometric titrations}

The EMF measurements were performed with a Schott Gerate TS165 pH-meter and the added volumes were measured using a Techware (Sigma) Digitrate dispenser $(25 \mathrm{~mL})$. Volumes of titrated aliquots were always $25 \mathrm{~mL}$.

$\mathrm{NaCl}$ was dried until constant weight and stored in a desecator. Stock $\mathrm{Cu}(\mathrm{II})$ solutions were standardized with EDTA [17]. All solutions were made in boiled tridistilled water cooled under a constant nitrogen flow. The solutions were freshly prepared prior to their use. Diluted solutions of $\mathrm{HCl}$ (Merck p.a.) were standardized against TRISMA-base (hydroxymethyl aminomethane). Diluted $\mathrm{NaOH}$ solutions were prepared from a saturated $\mathrm{NaOH}$ solution and standardized against the $\mathrm{HCl}$. In order to assess the degree of carbonate contamination, the method of Gran [18] was used. Cell compartments were kept at $25 \pm 0.1{ }^{\circ} \mathrm{C}$ with circulating water from a thermostated bath. The ionic strength was fitted at $0.150 \mathrm{M}$ with $\mathrm{NaCl}$ in the solutions. The glass electrode was calibrated by titration of a diluted $\mathrm{HCl}$ solution of known concentration with a standard base solution. It was checked separately in a solution with known $\left[\mathrm{H}^{+}\right]$before and after each titration.

In order to determine the dissociation constant values $\left(\mathrm{p} K_{\mathrm{a}}\right)$ of $\mathrm{ImzH}^{+}$and 2-OH-HipH $\mathrm{H}_{2}$ solutions of the respective ligands, in the absence of metal, were titrated. Further titrations were performed to study the ternary systems $\mathrm{Cu}^{2+} / 2-\mathrm{OH}-\mathrm{Hip}^{2-} / \mathrm{H}^{+}$and $\mathrm{Cu}^{2+} / \mathrm{Imz} / \mathrm{H}^{+}$in the 
Table 1

Crystal data and structure solution methods and refinement results for $\left[\mathrm{Cu}(\mathrm{Imz})_{4} \mathrm{Cl}_{2}\right]\left[\mathrm{Cu}(\mathrm{Imz})_{4} \mathrm{Cl}\right]_{2}(2-\mathrm{OH}-\mathrm{Hip})_{2}$ and $\left[\mathrm{Co}(2-\mathrm{OH}-\mathrm{Hip})(\mathrm{Imz})_{3}\right] \cdot \mathrm{H}_{2} \mathrm{O}$

\begin{tabular}{|c|c|c|}
\hline & {$\left[\mathrm{Cu}(\mathrm{Imz})_{4} \mathrm{Cl}_{2}\right]\left[\mathrm{Cu}(\mathrm{Imz})_{4} \mathrm{Cl}\right]_{2}(2-\mathrm{OH}-\mathrm{Hip})_{2}$} & {$\left[\mathrm{Co}(2-\mathrm{OH}-\mathrm{Hip})(\mathrm{Imz})_{3}\right] \cdot \mathrm{H}_{2} \mathrm{O}$} \\
\hline Empirical formula & $\mathrm{C}_{54} \mathrm{H}_{64} \mathrm{Cl}_{4} \mathrm{Cu}_{3} \mathrm{~N}_{26} \mathrm{O}_{8}$ & $\mathrm{C}_{18} \mathrm{H}_{20} \mathrm{CoN}_{7} \mathrm{O}_{5}$ \\
\hline Formula weight & 1537.73 & 473.34 \\
\hline Temperature (K) & $293(2)$ & \\
\hline Crystal system & Monoclinic & Orthorhombic \\
\hline Space group & $P 2_{1} / c(\# 14)$ & $P b c a(\# 61)$ \\
\hline \multicolumn{3}{|l|}{ Unit cell dimensions $\mathrm{a}^{\mathrm{a}}$} \\
\hline$a(\AA)$ & $16.880(1)$ & $11.712(2)$ \\
\hline$b(\AA)$ & $8.046(1)$ & $15.741(4)$ \\
\hline$c(\AA)$ & $24.683(1)$ & $22.254(4)$ \\
\hline$\beta\left(^{\circ}\right)$ & $107.88(1)$ & \\
\hline Volume $\left(\AA^{3}\right)$ & $3190.4(5)$ & 4103(1) \\
\hline$Z$, calc. density $\left(\mathrm{Mg} / \mathrm{m}^{3}\right)$ & $2,1.601$ & $8,1.533$ \\
\hline Absorpt. coeff. $\left(\mu, \mathrm{mm}^{-1}\right)$ & 1.234 & 6.962 \\
\hline$F(000)$ & 1578 & 1952 \\
\hline Crystal size (mm) & $0.02 \times 0.12 \times 0.16$ & $0.14 \times 0.24 \times 0.28$ \\
\hline Crystal color/shape & Blue/plate & Red/plate \\
\hline Diffractometer/scan & $\mathrm{KappaCCD} / \varphi$ and $\omega$ & Enraf-Nonius CAD- $4 / \omega-2 \vartheta$ \\
\hline Radiat., graph. monochr. & $\operatorname{MoK} \alpha, \lambda=0.71073 \AA$ & $\mathrm{CuK} \alpha, \lambda=1.54184 \AA$ \\
\hline$\vartheta$ range for data coll. & $2.84-25.00^{\circ}$ & $5.62-59.93^{\circ}$ \\
\hline Index ranges & $-20 \leqslant h \leqslant 20,-9 \leqslant k \leqslant 9,-29 \leqslant l \leqslant 29$ & $0 \leqslant h \leqslant 13,0 \leqslant k \leqslant 17,-1 \leqslant l \leqslant 24$ \\
\hline Reflections collected & 44709 & 3207 \\
\hline Independent reflections & $5605\left[R_{\text {int }}=0.061\right]$ & $3033\left[R_{\text {int }}=0.0997\right]$ \\
\hline Completeness & $92.5 \%\left(\right.$ to $\left.\vartheta=25^{\circ}\right)$ & $88.8 \%\left(\right.$ to $\left.\vartheta=59.93^{\circ}\right)$ \\
\hline Absorption correction & PLATON $^{1}$ & PLATON $^{1}$ \\
\hline Max. and min. transm. & 0.976 and 0.827 & 0.442 and 0.246 \\
\hline Obs. reflects. $[I>2 \sigma(I)]$ & 4781 & 1907 \\
\hline Data collection & COLLECT $^{2}$ & EXPRESS $^{3}$ \\
\hline \multirow{3}{*}{$\begin{array}{l}\text { Data red. and correct. }{ }^{\mathrm{b}} \\
\text { and struct. solut. }{ }^{\mathrm{c}} \text { and } \\
\text { refinement }{ }^{\mathrm{d}} \text { programs }^{\text {and }}\end{array}$} & DENZO and SCALEPACK ${ }^{4}$ & $\mathrm{XCAD}-4^{5}$ \\
\hline & SHELXS- $97^{6}$ & SHELXS- $97^{6}$ \\
\hline & SHELXL-977 & SHELXL-97 7 \\
\hline Refinement method & Full matrix least squares on $F^{2}$ & Full matrix least squares on $F^{2}$ \\
\hline \multirow[t]{2}{*}{ Weights, $w$} & {$\left[I>\sigma^{2}\left(F_{\mathrm{o}}^{2}\right)+(0.056 P)^{2}+4.07 P\right]^{-1}$} & {$\left[I>\sigma^{2}\left(F_{\mathrm{o}}^{2}\right)+(0.10 P)^{2}\right]^{-1}$} \\
\hline & $P=\left[\operatorname{Max}\left(F_{\mathrm{o}}^{2}, 0\right)+2 F_{\mathrm{c}}^{2}\right] / 3$ & $P=\left[\operatorname{Max}\left(F_{\mathrm{o}}^{2}, 0\right)+2 F_{\mathrm{c}}^{2}\right] / 3$ \\
\hline Data/restraints/param. & $5605 / 0 / 431$ & $3033 / 3 / 287$ \\
\hline Goodness-of-fit on $F^{2}$ & 1.038 & 0.974 \\
\hline Extinction & & $0.0010(1)$ \\
\hline Final $R$ ind..$^{\mathrm{e}}[I>2 \sigma(I)]$ & $R_{1}=0.0438, w R_{2}=0.1108$ & $R_{1}=0.0479, w R_{2}=0.1217$ \\
\hline$R$ indices (all data) & $R_{1}=0.0530, w R_{2}=0.1182$ & $R_{1}=0.0958, w R_{2}=0.1474$ \\
\hline Larg. peak and hole $\left(\mathrm{e} \AA^{3}\right)$ & 1.33 and -1.60 & 0.47 and -0.45 \\
\hline
\end{tabular}

${ }^{a}$ Least-squares refinement of the angular settings for 44709 reflections in the $2.84<\vartheta<25.00^{\circ}$ range for $\left[\mathrm{Cu}(\operatorname{Imz})_{4} \mathrm{Cl}_{2}\right]\left[\mathrm{Cu}\left(\mathrm{Imz}_{4} \mathrm{Cl}\right]_{2}(2-\mathrm{OHHip})_{2}\right.$ and 18 reflections in the range $16.05<\vartheta<32.34^{\circ}$ for $\left[\mathrm{Co}(2-\mathrm{OH}-\mathrm{Hip})(\operatorname{Imz})_{3}\right] \cdot \mathrm{H}_{2} \mathrm{O}$.

${ }^{\mathrm{b}}$ Corrections: Lorentz, polarization and numerical absorption. Extinction correction was applied to $\left[\mathrm{Co}(2-\mathrm{OH}-\mathrm{Hip})(\mathrm{Imz})_{3}\right] \cdot \mathrm{H}_{2} \mathrm{O}$.

${ }^{\mathrm{c}}$ Neutral scattering factors and anomalous dispersion corrections.

${ }^{\mathrm{d}}$ Structure solved by Patterson and Fourier methods. The final molecular model obtained by anisotropic full-matrix least-squares refinement of the non-hydrogen atoms.

${ }^{\mathrm{e}} R$ indices defined as: $R_{1} \sum|| F_{\mathrm{o}}|-| F_{\mathrm{c}}|| / \sum\left|F_{\mathrm{o}}\right|, w R_{2}=\left[\sum w\left(F_{\mathrm{o}}^{2}-F_{\mathrm{c}}^{2}\right)^{2} / \sum w\left(F_{\mathrm{o}}^{2}\right)^{2}\right]^{1 / 2}$.

actual experimental conditions. Sets of titrations with varying total concentrations and concentration ratios of the components were carried out to establish the equilibrium of the quaternary system $\mathrm{Cu}^{2+} / 2-\mathrm{OH}-\mathrm{Hip}^{2-}$ / $\mathrm{Imz} / \mathrm{H}^{+}$.

The formation constants denoted $\beta_{\mathrm{pqrs}}$ correspond to the general notation:

$$
\begin{aligned}
& p \mathrm{Cu}^{2+}+q 2-\mathrm{OH}-\mathrm{Hip}^{2-}+r \mathrm{Imz}+s \mathrm{H}^{+} \\
& \rightleftharpoons\left(\mathrm{Cu}^{2+}\right)_{p}\left(2-\mathrm{OH}-\mathrm{Hip}^{2-}\right)_{q}(\mathrm{Imz})_{r}\left(\mathrm{H}^{+}\right)_{s}
\end{aligned}
$$

A value of $\mathrm{p} K_{\mathrm{w}}=13.76$ (corresponding to $\log$ $\left.\beta_{000-1}=-13.76\right)$ was assumed for the experimental conditions $(T=298 \mathrm{~K}, I=150 \mathrm{mM})$.

\section{Results and discussion}

\subsection{Infrared spectroscopy}

The IR spectra of Imidazol, 2-OH-Hippuric acid, and the copper and cobalt complexes are compared in Table 2.

In both metal complexes the carboxylic acid coordinates as a deprotonated group. The band located at 1712 $\mathrm{cm}^{-1}$ for free 2-OH-HipH ${ }_{2}$ splits into two different bands, corresponding to the antisymmetric and symmetric stretching modes of the carboxylate moiety. The difference $\Delta v=v_{a}-v_{s}$, allows to establish the coordination of the $\mathrm{COO}^{-}$group to the metal $[19,20]$. In this case, these 
Table 2

Band positions and tentative assignment of the IR spectra of 2-hydroxyhippuric acid, Imidazol, [Co(2-OH-Hip)(Imz) $3 \cdot \mathrm{H}_{2} \mathrm{O}$ and $\left[\mathrm{Cu}(\mathrm{Imz})_{4} \mathrm{Cl}_{2}\right]\left[\mathrm{Cu}(\mathrm{Imz})_{4} \mathrm{Cl}\right]_{2}(2-\mathrm{OH}-\mathrm{Hip})_{2}$

\begin{tabular}{|c|c|c|c|c|}
\hline 2-OH-HipH ${ }_{2}$ & $\operatorname{Imz}$ & Co/2-OH-Hip/Imz & $\mathrm{Cu} / 2-\mathrm{OH}-\mathrm{Hip} / \mathrm{Imz}$ & Assignments \\
\hline $3358(\mathrm{~m})$ & & Overlapped $^{\mathrm{a}}$ & $3400(\mathrm{~m})$ & $v \mathrm{OH}$, phenol \\
\hline $1712(\mathrm{~s})$ & & & & $v \mathrm{COOH}$ \\
\hline \multirow[t]{2}{*}{$1624(\mathrm{~s})$} & & $1626(\mathrm{sh})$ & $1630(\mathrm{~s})$ & $v \mathrm{C}=\mathrm{O}$, amide $\mathrm{I}$ \\
\hline & & $1606(s)$ & $1595(\mathrm{~s})$ & $v_{a} \mathrm{COO}^{-}$ \\
\hline $1575(w)$ & & & & $\delta \mathrm{NH}, v_{s} \mathrm{~N}-\mathrm{C}=\mathrm{O}$ \\
\hline \multirow[t]{6}{*}{$1552(\mathrm{~s})$} & & & & amide II \\
\hline & $1579(w)$ & 1579 (sh) & & $v \mathrm{C}-\mathrm{C}, \delta_{i p} \mathrm{NH}$ \\
\hline & $1545(\mathrm{~m})$ & $1556(\mathrm{sh})$ & $1547(\mathrm{~m})$ & \\
\hline & $1499(\mathrm{~m})$ & $1532(\mathrm{~s})$ & $1501(\mathrm{~m})$ & \\
\hline & $1481(\mathrm{~m})$ & $1501(\mathrm{~m})$ & & \\
\hline & & $1373(\mathrm{~m})$ & 1390 (m,br) & $v_{\mathrm{s}} \mathrm{COO}^{-}$ \\
\hline \multirow[t]{3}{*}{$1363(w)$} & & & $1362(\mathrm{sh})$ & $\delta_{i p} \mathrm{OH}$, phenol \\
\hline & $661(\mathrm{~m})$ & $660(\mathrm{~m})$ & $656(\mathrm{~m})$ & Imidazol ring torsion \\
\hline & $619(\mathrm{~m})$ & $617(\mathrm{~m})$ & $613(\mathrm{~m})$ & $\mathrm{N}-\mathrm{H}$ out of plane bending \\
\hline
\end{tabular}

s: strong; m: medium; w: weak; sh: shoulder; br: broad.

a The broad band due to $\mathrm{OH}$ (water) stretchings masked the $\mathrm{OH}$ (phenol) stretching band.

values $\left(\Delta v(\mathrm{Co})=233 \mathrm{~cm}^{-1}\right.$ and $\left.\Delta v(\mathrm{Cu})=205 \mathrm{~cm}^{-1}\right)$, can be assigned to unidentate coordination and free anionic ligand, respectively. The stretching $\mathrm{C}=\mathrm{O}$ amide band [21] remains unaltered in the copper complex. In contrast, in the Co complex this band appears as a weak shoulder of the strong antisymmetric stretching band of $\mathrm{COO}^{-}$. This shift may indicate the ionization of the peptide $\mathrm{N}-\mathrm{H}$ hydrogen, since such ionization results in the resonance of the $\mathrm{O}-\mathrm{C}-\mathrm{N}$ system [20] and is indicative of the coordination of the amide nitrogen to the metal center. In this case it is not possible to analyze the $\mathrm{N}-\mathrm{H}$ stretching band of amide group to determine its deprotonation. This band appears in the same region (ca. $3400 \mathrm{~cm}^{-1}$ ) than those of Imidazol $\mathrm{N}-\mathrm{H}$ stretchings.

The phenolic $\mathrm{O}-\mathrm{H}$ stretching and bending modes of free 2-OH-HipH $\mathrm{H}_{2}$ are also observed in the copper complex, indicating the lacking of the interaction of this group with the metal ion. Unfortunately, it was more difficult to determine whether the phenolic group is coordinated or not to the cobalt center. On one hand, the band related to the $\delta(\mathrm{OH})$ mode is absent in the spectrum. On the other, the position of the characteristic $v(\mathrm{OH})$ band is within the region of the broad vibrational bands of water.

The participation of Imidazol in the coordination sphere of both metals is demonstrated by the appearance of the bands at ca. 660 and $620 \mathrm{~cm}^{-1}$ assigned to the ring torsion and $\mathrm{N}-\mathrm{H}$ out of plane bending modes of the Imidazol group, respectively [22].

\subsection{Thermal decomposition}

The thermal behavior of the solid complexes was investigated by means of TG and DTA measurements under a flowing $\mathrm{O}_{2}$ atmosphere up to $1000{ }^{\circ} \mathrm{C}$.

In the case of the copper complex the decomposition occurs in three stages. The first decomposition step is an endothermic process with a DTA signal at $194{ }^{\circ} \mathrm{C}$ (vw). The following successive processes are accompanied by exothermic DTA peaks located at 249, 253, 260, 288, 363,391 (sh) and $420{ }^{\circ} \mathrm{C}$. Only the latter one shows very strong intensity.

The total degradation process corresponds to:

$$
\begin{aligned}
& {\left[\mathrm{Cu}(\mathrm{Imz})_{4} \mathrm{Cl}_{2}\right]\left[\mathrm{Cu}(\mathrm{Imz})_{4} \mathrm{Cl}\right]_{2}(2-\mathrm{OH}-\mathrm{Hip})_{2}} \\
& \stackrel{\phi, \mathrm{O}_{2}}{\longrightarrow} 3 \mathrm{CuO}+\text { volatile products }
\end{aligned}
$$

The weight loss of $84.7 \%$ is in accordance with the calculated value: $84.5 \%$. The final residue was characterized by of IR spectroscopy.

From the thermal analysis of the cobalt complex it can be inferred that the first loss is associated to a water molecule, with a loss mass of 3.9\% (calculated, 3.8\%). After this step, four successive degradative processes take place. The very strong exothermic peak at $400{ }^{\circ} \mathrm{C}$ does not allow the observation of the other decomposition signals, in the DTA curve.

The overall reaction pattern can be formulated as:

$$
\begin{aligned}
& 2\left[\mathrm{Co}(2-\mathrm{OH}-\mathrm{Hip})(\mathrm{Imz})_{3}\right] \cdot \mathrm{H}_{2} \mathrm{O} \stackrel{\phi, \mathrm{O}_{2}}{\longrightarrow} \mathrm{Co}_{2} \mathrm{O}_{3} \\
& \quad+\text { volatile products }
\end{aligned}
$$

The final product has been identified by IR spectroscopy. The weight of the residue at $1000{ }^{\circ} \mathrm{C}$ is $17.3 \%$, in agreement with the theoretical value $17.5 \%$.

\subsection{Structural studies}

Fractional coordinates and equivalent isotropic displacement parameters for both complexes are available as supplementary material (see Section 6). Intra-molecular bond distances and angles around the metal ions in the $\left[\mathrm{Cu}(\mathrm{Imz})_{4} \mathrm{Cl}_{2}\right]\left[\mathrm{Cu}(\mathrm{Imz})_{4} \mathrm{Cl}\right]_{2}(2-\mathrm{OH}-\mathrm{Hip})_{2}$ and 
[Co(2-OH-Hip)(Imz $\left.)_{3}\right] \cdot \mathrm{H}_{2} \mathrm{O}$ substances are in Tables 3 and 4 , respectively. Figs. 1 and 2 show ORTEP [23] drawings of the complexes.

Table 3

Interatomic bond distances $(\AA)$ and angles $\left(^{\circ}\right)$ around copper in the $\left[\mathrm{Cu}(\mathrm{Imz})_{4} \mathrm{Cl}_{2}\right]\left[\mathrm{Cu}(\mathrm{Imz})_{4} \mathrm{Cl}\right]_{2}(2-\mathrm{OH}-\mathrm{Hip})_{2}$ complex $^{\mathrm{a}}$

\begin{tabular}{lc}
\hline Bond distances & \\
$\mathrm{Cu}(1)-\mathrm{N}(12)$ & $2.005(3)$ \\
$\mathrm{Cu}(1)-\mathrm{N}(11)$ & $2.024(3)$ \\
$\mathrm{Cu}(1)-\mathrm{Cl}(1)$ & $3.063(1)$ \\
$\mathrm{Cu}(2)-\mathrm{N}(23)$ & $1.993(2)$ \\
$\mathrm{Cu}(2)-\mathrm{N}(24)$ & $1.997(2)$ \\
$\mathrm{Cu}(2)-\mathrm{N}(21)$ & $2.040(2)$ \\
$\mathrm{Cu}(2)-\mathrm{N}(22)$ & $2.060(3)$ \\
$\mathrm{Cu}(2)-\mathrm{Cl}(2)$ & $2.826(1)$ \\
Bond angles & \\
$\mathrm{N}(12)-\mathrm{Cu}(1)-\mathrm{N}(11)$ & \\
$\mathrm{N}\left(12^{\prime}\right)-\mathrm{Cu}(1)-\mathrm{N}(11)$ & $89.4(1)$ \\
$\mathrm{N}(12)-\mathrm{Cu}(1)-\mathrm{Cl}(1)$ & $90.6(1)$ \\
$\mathrm{N}\left(12^{\prime}\right)-\mathrm{Cu}(1)-\mathrm{Cl}(1)$ & $89.74(8)$ \\
$\mathrm{N}(11)-\mathrm{Cu}(1)-\mathrm{Cl}(1)$ & $90.26(8)$ \\
$\mathrm{N}\left(11^{\prime}\right)-\mathrm{Cu}(1)-\mathrm{Cl}(1)$ & $88.22(8)$ \\
$\mathrm{N}(23)-\mathrm{Cu}(2)-\mathrm{N}(24)$ & $91.78(8)$ \\
$\mathrm{N}(23)-\mathrm{Cu}(2)-\mathrm{N}(21)$ & $172.1(1)$ \\
$\mathrm{N}(24)-\mathrm{Cu}(2)-\mathrm{N}(21)$ & $89.5(1)$ \\
$\mathrm{N}(23)-\mathrm{Cu}(2)-\mathrm{N}(22)$ & $90.7(1)$ \\
$\mathrm{N}(24)-\mathrm{Cu}(2)-\mathrm{N}(22)$ & $89.4(1)$ \\
$\mathrm{N}(21)-\mathrm{Cu}(2)-\mathrm{N}(22)$ & $89.5(1)$ \\
$\mathrm{N}(23)-\mathrm{Cu}(2)-\mathrm{Cl}(2)$ & $173.5(1)$ \\
$\mathrm{N}(24)-\mathrm{Cu}(2)-\mathrm{Cl}(2)$ & $93.22(9)$ \\
$\mathrm{N}(21)-\mathrm{Cu}(2)-\mathrm{Cl}(2)$ & $94.67(8)$ \\
$\mathrm{N}(22)-\mathrm{Cu}(2)-\mathrm{Cl}(2)$ & $90.38(7)$ \\
\hline & $96.10(8)$ \\
\hline
\end{tabular}

${ }^{\text {a }}$ Primed atoms are related to the unprimed ones by the inversion symmetry transformation $-x+1,-y+2,-z$.

Table 4

Interatomic bond distances $(\AA)$ and angles $\left({ }^{\circ}\right)$ around cobalt in the $\left[\mathrm{Co}(2-\mathrm{OH}-\mathrm{Hip})(\mathrm{Imz})_{3}\right] \cdot \mathrm{H}_{2} \mathrm{O}$ complex

\begin{tabular}{lr}
\hline Bond distances & $1.872(3)$ \\
$\mathrm{Co}-\mathrm{O}(41)$ & $1.873(4)$ \\
$\mathrm{Co}-\mathrm{N}(41)$ & $1.909(3)$ \\
$\mathrm{Co}-\mathrm{O}(43)$ & $1.922(4)$ \\
$\mathrm{Co}-\mathrm{N}(21)$ & $1.931(4)$ \\
$\mathrm{Co}-\mathrm{N}(11)$ & $1.945(4)$ \\
$\mathrm{Co}-\mathrm{N}(31)$ & \\
Bond angles & \\
$\mathrm{O}(41)-\mathrm{Co}-\mathrm{N}(41)$ & $94.9(1)$ \\
$\mathrm{O}(41)-\mathrm{Co}-\mathrm{O}(43)$ & $178.3(1)$ \\
$\mathrm{N}(41)-\mathrm{Co}-\mathrm{O}(43)$ & $84.0(1)$ \\
$\mathrm{O}(41)-\mathrm{Co}-\mathrm{N}(21)$ & $89.6(2)$ \\
$\mathrm{N}(41)-\mathrm{Co}-\mathrm{N}(21)$ & $91.9(2)$ \\
$\mathrm{O}(43)-\mathrm{Co}-\mathrm{N}(21)$ & $91.7(2)$ \\
$\mathrm{O}(41)-\mathrm{Co}-\mathrm{N}(11)$ & $89.1(2)$ \\
$\mathrm{N}(41)-\mathrm{Co}-\mathrm{N}(11)$ & $88.6(2)$ \\
$\mathrm{O}(43)-\mathrm{Co}-\mathrm{N}(11)$ & $89.6(2)$ \\
$\mathrm{N}(21)-\mathrm{Co}-\mathrm{N}(11)$ & $178.6(2)$ \\
$\mathrm{O}(41)-\mathrm{Co}-\mathrm{N}(31)$ & $91.8(1)$ \\
$\mathrm{N}(41)-\mathrm{Co}-\mathrm{N}(31)$ & $173.2(2)$ \\
$\mathrm{O}(43)-\mathrm{Co}-\mathrm{N}(31)$ & $89.2(1)$ \\
$\mathrm{N}(21)-\mathrm{Co}-\mathrm{N}(31)$ & $89.1(2)$ \\
$\mathrm{N}(11)-\mathrm{Co}-\mathrm{N}(31)$ & $90.5(2)$ \\
\hline
\end{tabular}

\subsection{1. $\left[\mathrm{Cu}(\mathrm{Imz}){ }_{4} \mathrm{Cl}_{2}\right]\left[\mathrm{Cu}(\mathrm{Imz}){ }_{4} \mathrm{Cl}\right]_{2}(2-\mathrm{OH}-\mathrm{Hip})_{2}$}

There are two distinct monomeric $\mathrm{Cu}(\mathrm{II})$ complexes, one elongated octahedral and neutral, $\left[\mathrm{Cu}(\mathrm{Imz})_{4} \mathrm{Cl}_{2}\right]$, sited at a crystallographic inversion center, the other one square pyramidal and positively charged, $\left[\mathrm{Cu}(\mathrm{Imz})_{4} \mathrm{Cl}\right]^{+}$.

In the centrosymmetric octahedral complex, copper(II) is equatorially coordinated to four Imidazol ligand groups $[\mathrm{Cu}-\mathrm{N}$ bond distances of 2.005(3) and 2.024(3) $\AA$ ] and axially to two chlorine ions $[\mathrm{d}(\mathrm{Cu}-$ $\mathrm{Cl})=3.063(1) \AA]$. Cis ligand- $\mathrm{Cu}-$ ligand angles are in the $88.22(8)-91.78(8)^{\circ}$ interval. One Imidazol ring lies close to the equatorial plane of ligand groups [dihedral angle of $6.0(3)^{\circ}$ ] whereas the other one is nearly perpendicular to this plane [angle of $89.3(1)^{\circ}$ ].

Copper(II) in the square pyramidal $\left[\mathrm{Cu}(\mathrm{Imz})_{4} \mathrm{Cl}\right]^{+}$ complex is in a quite similar equatorial coordination with four Imidazol ligand groups at the pyramid basis $[\mathrm{Cu}-\mathrm{N}$ distances in the range from 1.993(2) to 2.060(3) $\mathrm{A}]$, but now the metal is slightly out of the equatorial plane [0.126(1) $\AA$ apart] towards the chlorine ligand at the pyramid apex $[\mathrm{d}(\mathrm{Cu}-\mathrm{Cl})=2.826(1) \AA]$. Cis $\mathrm{N}-\mathrm{Cu}-\mathrm{N}$ and $\mathrm{N}-\mathrm{Cu}-\mathrm{Cl}$ angles are in the $89.4(1)-90.7(1)^{\circ}$ and 90.38(7)-96.10(8) intervals, respectively. Trans $\mathrm{N}-\mathrm{Cu}-$ $\mathrm{N}$ angles are 172.1(1) and $173.5(1)^{\circ}$. The 2-hydroxyhippuric acid molecule acts as counter ion negatively charged at its carboxylic end. The molecule HO-(ph)$(\mathrm{C}=\mathrm{O})-\mathrm{NH}-\mathrm{C}$ fragment is nearly coplanar with the phenyl ring, a conformation stabilized by a N$\mathrm{H} \cdots \mathrm{O}(\mathrm{ph})$ intramolecular bond $[\mathrm{d}(\mathrm{N} \cdots \mathrm{O} 1)=2.679 \AA]$.

The crystal is further stabilized by a H-bonding network involving a strong (phenyl)O- $\mathrm{H} \cdots \mathrm{O}$ (carboxyl) interaction $\left[\mathrm{d}\left(\mathrm{O} 1 \cdots \mathrm{O}^{\prime}\right)=2.590 \quad \mathrm{~A}\right], \quad(\mathrm{Imz}) \mathrm{N}-\mathrm{H} \cdots \mathrm{O}$ interactions with carboxylic and carbonyl oxygen atoms of neighboring 2-hydroxyhippuric acid molecules [the strongest with $\left.\mathrm{d}\left(\mathrm{N} 123 \cdots \mathrm{O}^{\prime}\right)=2.756 \mathrm{~A}\right],(\operatorname{Imz}) \mathrm{N}-\mathrm{H} \cdots$ $\mathrm{Cl}$ bonds [the strongest with $\mathrm{d}\left(\mathrm{N} 223 \cdots \mathrm{Cl} 2^{\prime}\right)=3.160 \mathrm{~A}$ ], and a strong (hip) $\mathrm{N}-\mathrm{H} \cdots \mathrm{O}($ phenyl) bond $[\mathrm{d}(\mathrm{N} \cdots \mathrm{O} 1)=$ $2.679 \mathrm{~A}]$. H-bond distances and angles are detailed in the supplementary Table S9. ${ }^{1}$

\subsection{2. $\left[\mathrm{Co}(2-\mathrm{OH}-\mathrm{Hip})(\mathrm{Imz})_{3}\right] \cdot \mathrm{H}_{2} \mathrm{O}$}

The cobalt(III) ion is in a slightly distorted octahedral environment, equatorially coordinated to the three Imidazol ligand groups [Co-N distances of 1.922(4), 1.931(4) and 1.945(4) A] and the nitrogen atom of a triply deprotonated 2-hydroxyhippuric acid molecule $[\mathrm{d}(\mathrm{Co}-\mathrm{N})=1.873(4) \AA]$. This molecule acts as tridentate ligand by completing the six fold coordination around Co with the phenyl and one of the carboxylate oxygen atoms at the octahedron axial positions [ $\mathrm{Co}-\mathrm{O}$ distances of 1.872(3) and 1.909(3) $\AA$, respectively]. As seen along the $\mathrm{O}-\mathrm{Co}-\mathrm{O}$ axis, the Imidazol ligand groups are arranged in a propeller-like conformation. Cis and trans

\footnotetext{
${ }^{1}$ Supplementary tables available in the online version.
} 

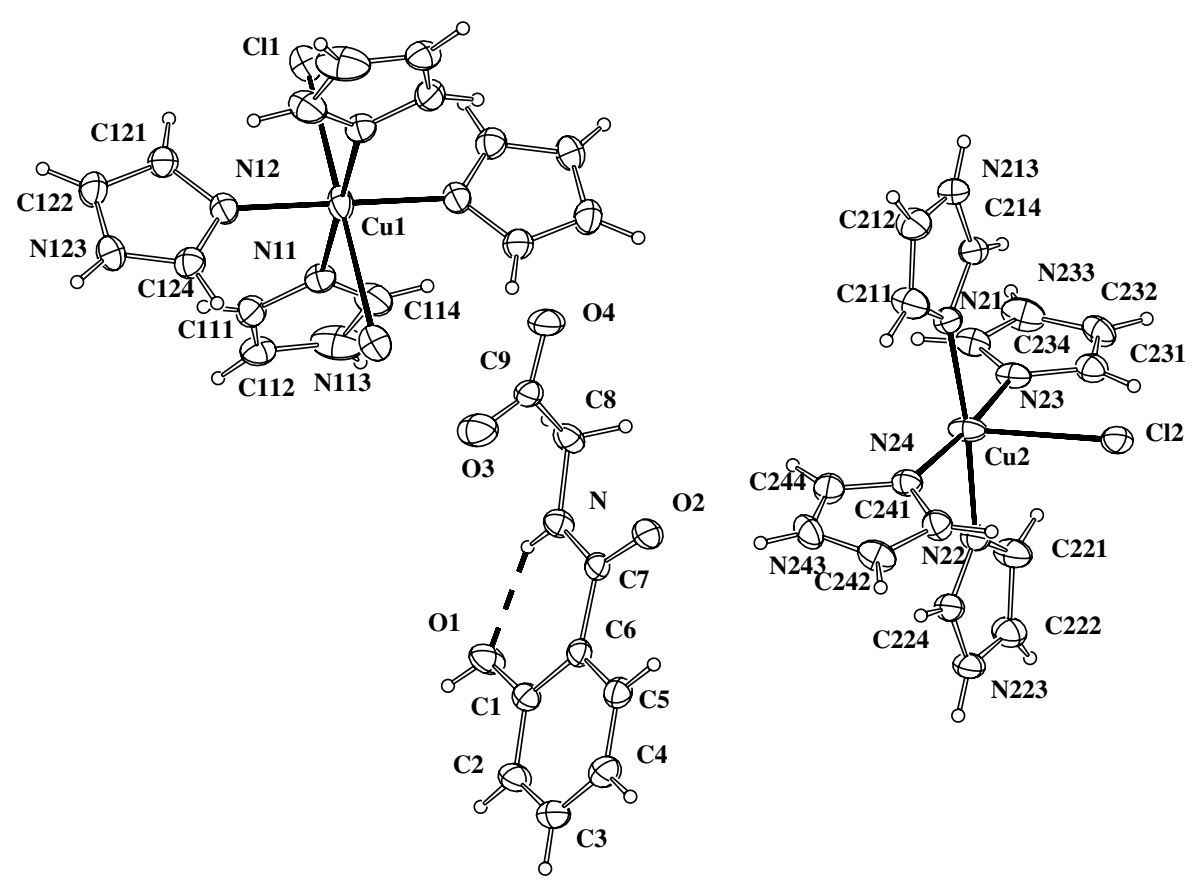

Fig. 1. Molecular drawing of $\left[\mathrm{Cu}(\mathrm{Imz})_{4} \mathrm{Cl}_{2}\right]\left[\mathrm{Cu}(\mathrm{Imz})_{4} \mathrm{Cl}\right]_{2}(2-\mathrm{OH}-\mathrm{Hip})_{2}$ complex showing the labels for the non- $\mathrm{H}$ atoms and their displacement ellipsoids at the $30 \%$ probability level. Cooper(II)-ligand bonds are emphasized by full lines. Only one $\mathrm{Cu}(\mathrm{Imz})_{4} \mathrm{Cl}$ complex and one 2 -hydroxyhippuric acid anion are shown.

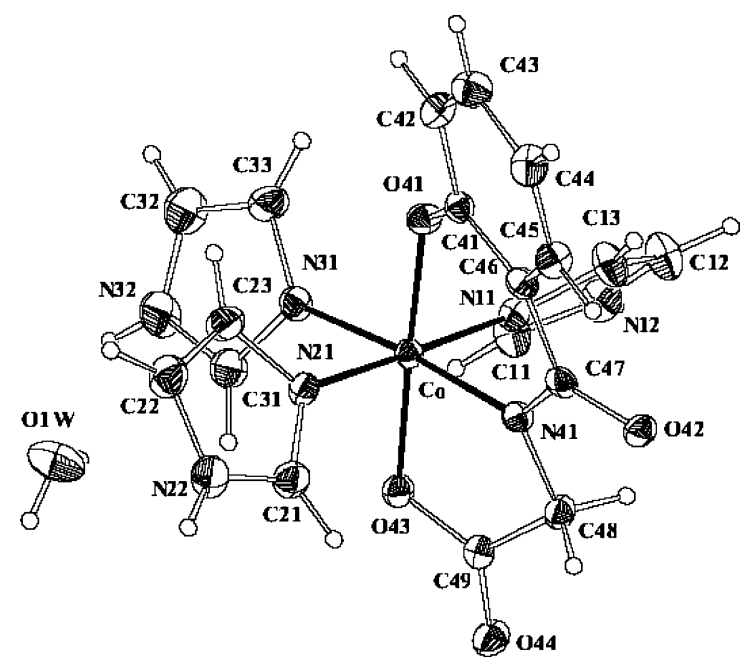

Fig. 2. Molecular plot of $\left[\mathrm{Co}(2-\mathrm{OH}-\mathrm{Hip})(\mathrm{Imz})_{3}\right] \cdot \mathrm{H}_{2} \mathrm{O}$.

ligand-Co-ligand angles are in the $84.0(1)-94.9(1)^{\circ}$ and 173.2(2)-178.6(2) intervals, respectively.

The lattice presents a net of $(\mathrm{Imz}) \mathrm{N}-\mathrm{H} \cdots \mathrm{O}$ involving as acceptors the 2-hydroxyhippuric acid, unbonded to metal, carboxylic oxygen $\left[\mathrm{d}\left(\mathrm{N} 12 \cdots \mathrm{O} 44^{\prime}\right)=2.711 \mathrm{~A}\right]$, the carbonyl oxygen atom $\left[\mathrm{d}\left(\mathrm{N} 22 \cdots \mathrm{O} 42^{\prime \prime}\right)=2.760 \mathrm{~A}\right]$, and the water oxygen $[\mathrm{d}(\mathrm{N} 32 \cdots \mathrm{O} 1 \mathrm{w})=2.825 \mathrm{~A}]$. The water molecule, in turn, acts as donor in a pair of Ow$\mathrm{H} \cdots \mathrm{O}$ bonds with the 2-hydroxyhippuric acid carbonyl atom $\left[\mathrm{d}\left(\mathrm{O} 1 \mathrm{w} \cdots \mathrm{O} 42^{\prime}\right)=2.757 \mathrm{~A}\right]$ and the phenyl oxy- gen atom $\left[\left(\mathrm{O} 1 \mathrm{w} \cdots \mathrm{O} 41^{\prime \prime}\right)=2.917 \mathrm{~A}\right]$. The H-bonding structure is detailed in the supplementary Table S10. ${ }^{1}$

\subsection{Electronic spectra}

Six coordinated complexes of cobalt(III) are generally mostly low spin and diamagnetic $\left({ }^{1} \mathrm{~A}_{1 \mathrm{~g}}\right.$ ground term). Two transitions to the ${ }^{1} \mathrm{~T}_{1 \mathrm{~g}}$ and ${ }^{1} \mathrm{~T}_{2 \mathrm{~g}}$ states are observed [24]. For trans-complexes, the ${ }^{1} \mathrm{~T}_{1 \mathrm{~g}}$ state is splitted in two levels and a three-band pattern could be observed in this case (see Table 5). The formation of the trans-isomer is also confirmed by the crystalline structure determination of the cobalt complex. The electronic absorption spectrum (UV-Vis) of the aqueous solution and the diffuse reflectance spectrum of the solid, show

Table 5

Electronic absorption bands for $\left[\mathrm{Co}(2-\mathrm{OH}-\mathrm{Hip})(\mathrm{Imz})_{3}\right] \cdot \mathrm{H}_{2} \mathrm{O}$ and $\left[\mathrm{Cu}(\mathrm{Imz})_{4} \mathrm{Cl}_{2}\right]\left[\mathrm{Cu}(\mathrm{Imz})_{4} \mathrm{Cl}\right]_{2}$ (2-OH-Hip) $)_{2}$

\begin{tabular}{lll}
\hline & UV-Vis $^{\mathrm{a}}$ & Diffuse reflectance $^{\mathrm{a}}$ \\
\hline $\mathrm{Co} / 2-\mathrm{OH}-\mathrm{Hip} / \mathrm{Imz}$ & $404(1123)$ & 405 \\
& $502(582)$ & 505 \\
& $602(442)$ & 590 \\
$\mathrm{Cu} / 2-\mathrm{OH}-\mathrm{Hip} / \mathrm{Imz}$ & $382(130)$ & 370 \\
& $628, \mathrm{br}(65)$ & 550 \\
& & 660 \\
& & 750
\end{tabular}

${ }^{\mathrm{a}}$ Wavelength, $\mathrm{nm}$. Parenthesis, molar extinction coefficient, $\mathrm{M}^{-1}$ $\mathrm{cm}^{-1}$. br: broad. 
the three-band pattern, denoting the conservation of the coordination sphere upon dissolution.

The dissolution of the blue crystals of $\left[\mathrm{Cu}(\mathrm{Imz})_{4} \mathrm{Cl}_{2}\right]\left[\mathrm{Cu}(\mathrm{Imz})_{4} \mathrm{Cl}\right]_{2}(2-\mathrm{OH}-\mathrm{Hip})_{2}$ in water results in a green solution, indicating a change in the coordination sphere around the metal center. The optical spectrum (Table 5) consists in a broad band near $628 \mathrm{~nm}$ (band I) and a second one near $382 \mathrm{~nm}$ (band II). The former can be associated to the characteristic single broad poorly resolved absorption band in the visible region. High molar absorptivities are typically related to strong tetragonal distortion [24]. Nevertheless, the extinction coefficients given in Table 5 are apparent values due to the contribution of other species in the solution at $\mathrm{pH}=5.5$ (see Potentiometric Titrations section). The band located at $382 \mathrm{~nm}$ is indicative of a charge transfer $\mathrm{O}^{-}-\mathrm{Cu}$ transition denoting the deprotonation and coordination of the phenolate group [3,25].

The broad band in the reflectance spectrum of the crystalline solid that appears at the $450-830 \mathrm{~nm}$ region is assigned to the $d-d$ transitions of each copper atom, with different coordination number. This band is usually broad and it is originated by the $x z, y z \rightarrow x^{2}-y^{2}$ transitions with a shoulder at lower energies due to the $z^{2} \rightarrow x^{2}-y^{2}$ transition. The latter should occur at higher energy in the five coordinate complex. It can be explained by the tetragonal distortion caused by a single axial ligand, greater than that produced by two axial ligands in a six coordinated center. The diffuse reflectance spectrum shows the overlapping of the characteristic spectra of these two kind of complexes.

The magnetic moment value of the copper complex $(\mu=1.50 \mathrm{BM})$ is close to that calculated for the spinonly $d^{9}$ configuration. The expected range of values for mononuclear $\mathrm{Cu}(\mathrm{II})$ complexes is usually higher (1.7-1.9 BM) [26]. As can be seen in the packing schema (Fig. 3), the copper centers of the complexes are interconnected. Ionic (monopole-monopole) and electrostatic interactions (monopole-dipole, dipole-dipole, van der Waals, $\mathrm{H}$ bondings) are involved. The bond distances $\mathrm{Cu}-$ $\mathrm{Cl} \cdots \mathrm{Cu}$ are 3.063 and $3.46 \AA$, respectively, giving rise to a polymeric structure. This interaction can probably be the reason of the antiferromagnetic coupling between the aligned metal centers.

The cobalt complex is diamagnetic, denoting the oxidation of the metal center in the preparation of the compound.

\subsection{Potentiometric titrations}

Although the aqueous equilibrium of the ligands has been extensively studied, deprotonation constants were recalculated from different sets of titrations and using Best calculation program [27]. These results (2-OH$\left.\mathrm{HipH}_{2}: \mathrm{p} K_{1}=3.35, \mathrm{p} K_{2}=8.10 ; \mathrm{ImzH}^{+}: \mathrm{p} K=7.24\right)$ are in accordance with reported data [3-5,28].

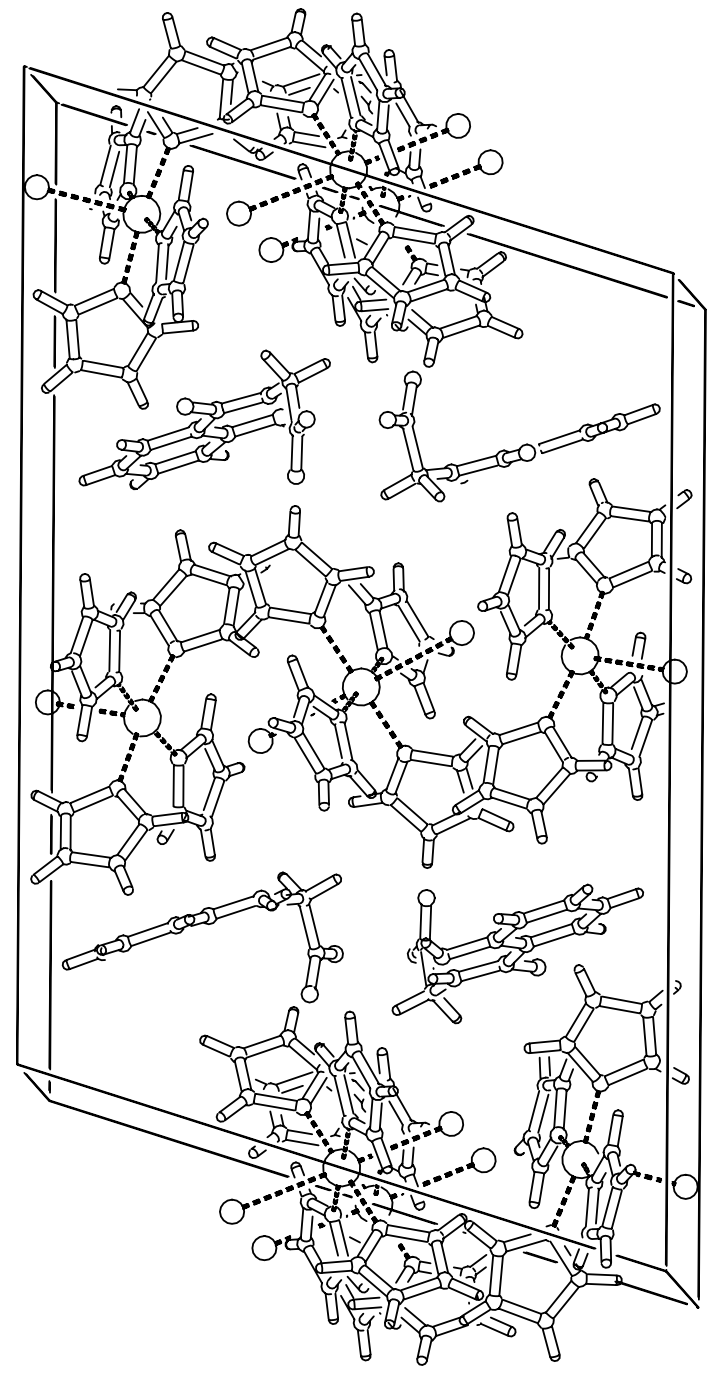

Fig. 3. Packing of copper compounds to generate linear structures between them

To determine the formation constants of the ternary $\left(\mathrm{Cu}^{2+} / 2-\mathrm{OH}-\mathrm{Hip}^{2-} / \mathrm{H}^{+}\right.$and $\left.\mathrm{Cu}^{2+} / \mathrm{Imz} / \mathrm{H}^{+}\right)$and quaternary $\left(\mathrm{Cu}^{2+} / 2-\mathrm{OH}-\mathrm{Hip}^{2-} / \mathrm{Imz}^{-\mathrm{H}^{+}}\right)$systems, data collected from several sets of titrations were analyzed with Best and Superquad calculation programs [29]. The usual criteria for this kind of programs $\left(\mathrm{CHI}^{2}, R\right.$ values, standard deviations, etc.) were used to select the equilibrium model of speciation.

The results obtained for the $\mathrm{Cu}^{2+} / \mathrm{Imz} / \mathrm{H}^{+}$system were in agreement with the literature [26]. The $\mathrm{Cu}^{2+} / 2-$ $\mathrm{OH}-\mathrm{Hip}^{2-} / \mathrm{H}^{+}$equilibrium has been previously studied by González et al. [3] and, afterwards by Bavoso et al. [4]. Each author has proposed a different speciation model and our data fitted much well with the former one.

Several models for the $\mathrm{Cu}^{2+} / 2-\mathrm{OH}-\mathrm{Hip}^{2-} / \mathrm{Imz} / \mathrm{H}^{+}$ equilibrium have been tested in this work, based on ternary species and reported results for related systems $[3,4,28]$. In Table 6 the proposed model for the quaternary 
Table 6

Composition, notation and formation constants $(\beta)$ for the $\mathrm{Cu}^{2+} / 2$ $\mathrm{OH}-\mathrm{Hip}^{2-}(\mathrm{L}) / \mathrm{Imz}(\mathrm{A}) / \mathrm{H}^{+}$system $\left(0.150 \mathrm{M} \mathrm{NaCl}, 25^{\circ} \mathrm{C}\right)$

\begin{tabular}{llr}
\hline Species & Formula & $\log \beta$ \\
\hline 0011 & $\mathrm{AH}^{+}$ & 7.24 \\
0101 & $\mathrm{LH}^{-}$ & 8.10 \\
0102 & $\mathrm{LH}_{2}$ & 11.45 \\
1010 & {$\left[\mathrm{CuA}^{2+}\right.$} & 4.43 \\
1020 & {$\left[\mathrm{CuA}_{2}\right]^{2+}$} & 7.77 \\
1030 & {$\left[\mathrm{CuA}_{3}\right]^{2+}$} & 10.95 \\
1040 & {$\left[\mathrm{CuA}_{4}\right]^{2+}$} & 12.60 \\
1100 & {$\left[\mathrm{CuL}^{2}\right.$} & 5.54 \\
$110-1$ & {$\left[\mathrm{CuLH}_{-1}\right]^{-}$} & 0.93 \\
$110-2$ & {$\left[\mathrm{CuLH}_{-2}\right]^{2-}$} & -9.34 \\
1120 & {$\left[\mathrm{CuLA}_{2}\right]^{-}$} & 14.37 \\
$113-1$ & {$\left[\mathrm{CuLA}_{3} \mathrm{H}_{-1}\right]^{-}$} & 10.09 \\
$112-2$ & {$\left[\mathrm{CuLA}_{2} \mathrm{H}_{-2}\right]^{2-}$} & 1.52 \\
\hline
\end{tabular}

system and the corresponding $\beta$ values for the species are shown.

The species distribution as a function of $\mathrm{pH}$, in the 212 range, was obtained with SPECIES program and is depicted in Fig. 4.

The results show that complexation occurs from $\mathrm{pH}$ values as low as 2.5 , even for total concentrations $5 \mathrm{mM}$ $\mathrm{Cu}^{2+}, 10 \mathrm{mM}$ 2-OH-Hip and $20 \mathrm{mM}$ Imz. Ternary (1100 and 1010) species are formed in the lower $\mathrm{pH}$ range. Appearance of quaternary complexes starts at around $\mathrm{pH}=4$ and prevails at higher $\mathrm{pH}$ values. From the formation constant values it can be observed that conversion of ternary species, initially present in solution, into the 1120 complex, are favored against the foregoing addition of Imidazol ligand or further deprotonation of 2-hydroxyhippuric acid, with increasing $\mathrm{pH}$.

Although the distribution species is sensitive to total concentration and concentration ratios of the components, 1120 species is found to be the main one in the 5$6 \mathrm{pH}$ range. The 112-2 species invariable appears as the most abundant at higher $\mathrm{pH}$ values. The latter species is

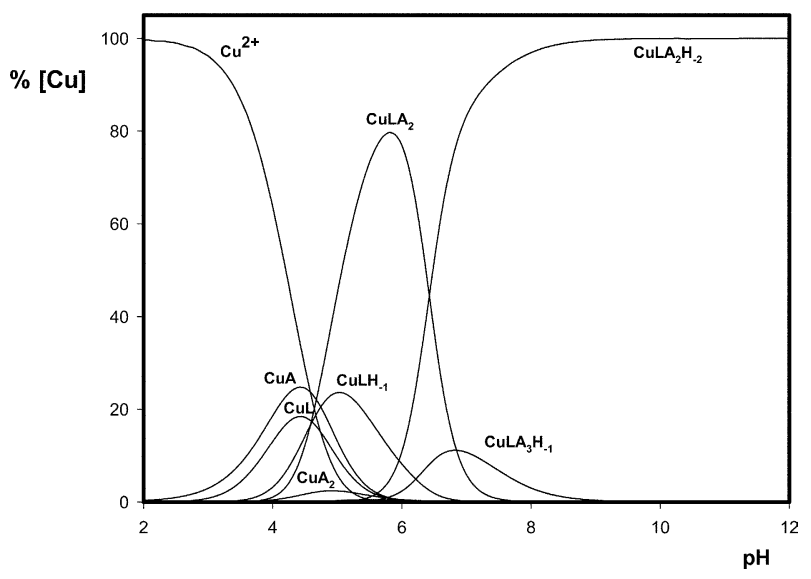

Fig. 4. Species distribution for the system: copper(II), 2-hidroxyhippuric acid (L) and Imidazol (A) $(5 \mathrm{mM}: 10 \mathrm{mM}: 20 \mathrm{mM})$ as a function of $\mathrm{pH}$ at $25^{\circ} \mathrm{C}, I=0.150 \mathrm{M} \mathrm{NaCl}$. expected to have the deprotonated amide nitrogen of the 2-OH-Hip coordinating the metal. Such coordination arrangement was observed at the studied $\mathrm{Co}(\mathrm{II})$ compound and is proposed for 2-OH-Hip complexes of $\mathrm{Cu}(\mathrm{II})$ [3], $\mathrm{Fe}(\mathrm{III})$ [6] and $\mathrm{VO}(\mathrm{IV})$ [5] in the alkaline region. The sixth position is then occupied by a deprotonated aqua ligand.

Even when the relative Imidazol concentration is increased up to $\mathrm{Cu}: \mathrm{A}=1: 4$, the 113-1 complex remains as a minor species in the distribution. Higher Imidazol/ metal concentration ratio is needed to attach the third and fourth molecule to $\mathrm{Cu}(\mathrm{II})$, in the ternary system. Moreover, the 2-OH-Hip present in solution competes with Imidazol in the complexation process.

Extreme concentration of solution and addition of ethanol was needed to obtained the solid complex that contains a $\mathrm{Cu}: 2-\mathrm{OH}-\mathrm{Hip}: \mathrm{Imz}$ ratio equal to $3: 2: 12$. The speciation, determined in the conditions of the aqueous dissolution of the crystalline sample, shows the presence of 1120 and 112-2 as dominant complex species. Minor ternary species are also present in solution. This explains the differences between the electronic spectrum of the mentioned solution and the diffuse reflectance spectrum of the solid, as discussed above.

\section{Conclusion}

Two new ternary crystalline metal complexes with salicylglycine and Imidazol are obtained and characterized in this work. These complexes are presented as models of natural systems. The coordination of the cobalt complex shows the usual characteristics of other transition metal complexes involving amide deprotonation. The dissymmetrical structure is similar to that observed in the metal binding sites of biologically relevant metallo-proteins containing Schiff base type ligands. Notwithstanding, the copper complex structure appears as an interesting model for $\mathrm{Cu}-\mathrm{Cu}$ interactions in several biological systems (electron transfers, superoxide dismutase and catalase) and biomaterials (metalorganic framework). Chemical speciation in solution offers valuable information about metal bioavailability and transport, involved in many important physiological functions.

\section{Supplementary information available ${ }^{2}$}

Tables of fractional coordinates and equivalent isotropic displacement parameters for both complexes (Tables S1 and S2), full intra-molecular bond distances and angles (Tables S3 and S4, respectively), atomic an-

\footnotetext{
${ }^{2}$ Supplementary tables available in the online version.
} 
isotropic displacement parameters (Tables S5 and S6), hydrogen atoms positions (Tables S7 and S8), H-bond distances and angles (Tables S9 and S10), and observed and calculated structure factor amplitudes.

\section{Acknowledgements}

This work was supported by CONICET, CIC-PBA and ANPCyT (PICT 06-06148 and 00375) and by a collaborative agreement between CONICET of Argentina and CNPq of Brazil and by FAPESP of Brazil. EGF, ACGB and OEP are members of the Research Career from CONICET. PAMW is a member of the Research Career from CICPBA.

\section{References}

[1] M.C. Capllonch, A. García-Raso, A. Terrón, M.C. Apella, E. Espinosa, E. Molins, J. Inorg. Biochem. 85 (2001) 173-178.

[2] A. Latif Abuhijleh, C. Woods, Inorg. Chim. Acta 194 (1992) 9-14.

[3] E.B. Gonzalez, L.N. Daeid, K.B. Nolan, E. Farkas, Polyhedron 13 (1994) 1495-1499.

[4] A. Bavoso, L. Menabue, M. Saladini, M. Sola, Inorg. Chim. Acta 244 (1996) 207-212.

[5] T. Kiss, K. Petrohán, P. Buglyó, K. Sanna, G. Micera, J. Costa Pessoa, C. Madeira, Inorg. Chem. 37 (1998) 6389-6391.

[6] J.G. Muller, C.J. Burrows, Inorg. Chim. Acta 275-276 (1998) 314 319.

[7] T. Kiss, T. Jakusch, M. Kilyén, E. Kiss, A. Lakatos, Polyhedron 19 (2000) 2389-2401.

[8] A. Jancsó, T. Gajda, A. Szorcsik, T. Kiss, B. Henry, G. Vankó, P. Rubini, J. Inorg. Biochem. 83 (2001) 187-192.

[9] D.R. Smith, Coord. Chem. Rev. 172 (1998) 457-573.

[10] A.L. Spek, Acta Cryst. A 46 (1990) C34.
[11] Enraf-Nonius COLLECT, Nonius BV, Delft, The Netherlands, 1997-2000.

[12] CAD4 Express Software, Enraf-Nonius, Delft, The Netherlands, 1994.

[13] Z. Otwinowski, W. Minor, in: C.W. Carter Jr., R.M. Sweet (Eds.), Methods in Enzymology, vol. 276, Academic Press, New York, 1997, pp. 307-326.

[14] K. Harms, S. Wocadlo, XCAD-4, Program for Processing CAD-4 Diffractometer Data, University of Marburg, Marburg, Germany, 1995.

[15] G.M. Sheldrick, SHELXS-97, Program for Crystal Structure Resolution, University of Göttingen, Göttingen, Germany, 1997.

[16] G.M. Sheldrick, SHELXL-97, Program for Crystal Structures Analysis, University of Göttingen, Göttingen, Germany, 1997.

[17] I.M. Kolthoff, E.B. Sandell, E.J. Meehan, S. Bruckenstein, Análisis Químico Cuantitativo, fifth ed., Librería y editorial Nigar, Buenos Aires, 1979.

[18] G. Gran, Analyst 77 (1952) 661-671.

[19] G.B. Deacon, R.J. Phillips, Coord. Chem. Rev. 33 (1980) 227-250.

[20] K. Nakamoto, Infrared and Raman Spectra of Inorganic and Coordination Compounds, fourth ed., Wiley, New York, 1986.

[21] E. Pretsch, T. Clerc, J. Seibl, W. Simon, Tables of Spectral Data for Structure Determination of Organic Compounds, second ed., Springer, Berlin, 1989.

[22] E.J. Baran, E.G. Ferrer, M.C. Apella, Monatsh. Chem. 122 (1991) 21-26.

[23] C.K. Johnson, ORTEP-II, A Fortran Thermal-Ellipsoid Plot Program, Report ORNL-5318, Oak Ridge National Laboratory, Tennessee, USA, 1976.

[24] A.B.P. Lever, Inorganic Electronic Spectroscopy, second ed., Elsevier, The Netherlands, 1984.

[25] C. Livera, L.D. Pettit, M. Bataille, J. Krembel, W. Bal, H. Kozlowski, J. Chem. Soc., Dalton Trans. (1988) 1357-1360.

[26] F.A. Cotton, G. Wilkinson, C.A. Murillo, M. Bochmann, Advanced Inorganic Chemistry, sixth ed., Wiley, New York, 1999.

[27] A.E. Martell, R.J. Motekaitis, Determination and Use of Stability Constants, second ed., VCH Publishers Inc., New York, 1992.

[28] A.E. Martell, R.M. Smith, Critical Stability Constants, Plenum Press, New York, 1974.

[29] P. Gans, A. Sabatini, A. Vacca, J. Chem. Soc., Dalton Trans. (1985) 1195-1200. 